\title{
Faktor-Faktor yang Memengaruhi Hubungan Kelekatan Ibu terhadap Janin dalam Kandungan
}

\section{Factors Affecting Maternal Fetal Attachment}

\author{
Sulistami Prihandini ${ }^{1}$, Linda Primana ${ }^{2}$ \\ 1,2 Fakultas Psikologi, Universitas Indonesia
}

\begin{abstract}
Based on previous studies, it has been known that maternal fetal attachment, significantly affects the health of mother's pregnancy and the optimization of infant development. This literature review wants to find out what factors influence maternal fetal attachment. After extracting 343 articles, 9 articles were discussed. As the result, there are several demographic and psychological variables that significantly influence maternal fetal attachment. Demographic variables that influence maternal fetal attachment are age, maternal education, socioeconomic status, number of children, type of pregnancy (parity), pregnancy plan, previous pregnancy, impaired pregnancy and gestational age. On the other hand, psychological influences on maternal and fetal attachment are depression, social support, family atmosphere, anxiety, self-compassion, and pregnant mother's ability to be close and trusting to other people.
\end{abstract}

Kata kunci: fetus attachment; maternal fetal attachment; psychology of pregnant mother

Abstrak. Berdasarkan penelitian-penelitian sebelumnya, diketahui bahwa kelekatan hubungan antara ibu hamil dengan janin dalam kandungan, berpengaruh secara signifikan terhadap kesehatan kehamilan ibu serta optimalisasi perkembangan bayi tersebut ketika telah dilahirkan. Tinjauan literatur ini hendak mengetahui faktor apa saja yang memengaruhi kelekatan hubungan antara ibu dan bayi yang berada dalam kandungan (maternal fetal attachment). Setelah dilakukan ekstraksi dari 343 artikel, didapatkan 9 artikel yang dibahas dalam tinjauan literatur ini. Hasilnya, terdapat beberapa variabel demografis dan variabel psikologis yang secara signifikan berpengaruh terhadap kelekatan ibu dan janin. Variabel demografis yang berpengaruh terhadap kelekatan ibu dan janin yaitu usia, pendidikan ibu, status sosial ekonomi, jumlah anak sebelumnya, jenis kehamilan (parity), perencanaan kehamilan, kehamilan sebelumnya, gangguan kehamilan dan usia kehamilan. Di lain pihak, psikologis yang berpengaruh terhadap kelekatan ibu dan janin adalah depresi, dukungan sosial, kecemasan, selfcompassion, suasana keluarga, serta kemampuan ibu untuk dekat dan percaya terhadap orang dewasa lain.

Kata kunci: maternal fetal attachment; ibu dan janin; psikologi ibu hamil

\section{Pengantar}

Survei Demografi dan Kesehatan Indonesia (SDKI) menyebutkan bahwa

\footnotetext{
* Korespondensi mengenai artikel ini dapat melalui: 11defazila@gmail.com
}

pada tahun 2012, angka kematian ibu (AKI) di Indonesia yaitu sebesar 359 per 100.000 kelahiran (Kementerian Kesehatan RI, 2014). Tinjauan literatur yang dilakukan oleh Mgawadere, Kana, \& van den Broek (2017) mengenai angka 
kematian ibu di 60 negara berpenghasilkan rendah dan menengah, di antaranya seperti China, Republik Dominica, Brazil, Mesir, Nigeria, Cameroon, Malawi, Zambia, India, Pakistan, dan Turki, menunjukkan angka rata-rata 519 per 100.000 kelahiran. Badan kesehatan dunia (World Health Organization) menargetkan pada tahun 2030, tidak satu negarapun yang angka kematian ibu hamil dan melahirkan di atas 70 per 100.000 kelahiran (Mgawadere et al., 2017). Ditinjau dari target WHO untuk tahun 2030, kondisi angka kematian ibu untuk Indonesia dan negara-negara berpenghasilan rendah dan menengah masih tinggi.

Sumber berita Kompas.com (2014) menyebutkan bahwa di Indonesia sendiri, Jawa Barat merupakan penyumbang angka kematian ibu terbesar. Di Propinsi Jawa Barat, Kabupaten Sukabumi menjadi daerah yang paling tinggi dalam angka kematian ibu. Dr. Lily S. Sulistyowati dari Kementerian Kesehatan Republik Indonesia, juga menyebutkan bahwa Indonesia dapat dikatakan memiliki angkat kematian ibu tertinggi di kawasan Asia Tenggara (Erviana, 2014). Masalah mengenai tingginya angka kematian ibu sudah dipahami oleh sebagian masyarakat. Hal ini terbukti dengan data Riskesdas 2013 tentang Perilaku Hidup Bersih dan Sehat di mana jumlah persalinan yang dilakukan oleh tenaga kesehatan terbilang tinggi, yaitu 87,6\%. Meskipun demikian, angka kematian ibu hamil dan melahirkan tetap tinggi (Erviana, 2014). Oleh karena itu, tingginya angka kematian ibu diprediksi bukan hanya disebabkan oleh kurangnya tenaga kesehatan, namun ada faktor lain yang memengaruhinya.

Hal ini mungkin disebabkan adanya faktor lain yang memengaruhi tingginya angka kematian ibu. Kemungkinan faktor lain yang turut memengaruhi angka kematian ibu adalah faktor psikologi atau mental yang memengaruhi kesehatan ibu hamil secara fisik. Oleh karena itu, kesehatan mental dan fisik selama kehamilan merupakan faktor penting yang harus diperhatikan, khususnya dalam menghadapi tingginya Angka Kematian Ibu hamil dan melahirkan. Hal ini disebabkan karena kondisi mental yang tidak sehat dapat memengaruhi kondisi fisik ibu ketika hamil dan melahirkan (Retnowati, 2011).

Terdapat banyak faktor yang dapat memengaruhi kesehatan mental ibu hamil yang akan memengaruhi kesehatan fisiknya, diantaranya yaitu kelekatan antara ibu hamil dan janin dalam kandungan (Golbasi, Ucar, \& Tugut, 2015). Berdasarkan penelitian sebelumnya, ditemukan bahwa kelekatan antara ibu hamil dan janin ditemukan berkorelasi dengan kesadaran ibu mengenai praktik kesehatan terkait kehamilan, seperti kemauan menerima perawatan selama kehamilan dan kesadaran dalam mematuhi perawatan kehamilan yang disarankan serta mengurangi konsumsi alkohol selama kehamilan (Golbasi et al., 2015). Penelitian tersebut membuktikan bahwa kelekatan ibu hamil dan janin juga berkontribusi terhadap kesehatan kehamilan (Cunningham, 2008).

Hubungan emosional atau kelekatan antara ibu dan janin dalam kandungan sebelum dilahirkan, disebut dengan fetus attachment (Condon, 1993). Fetus attachment berasal dari teori kelekatan (attachment theory) (Brandon, Pitts, Denton, Stringer, \& Evans, 2009). Bowlby menjelaskan bahwa kelekatan yang terjadi pada awal kehidupan seorang anak akan memengaruhi perkembangan selanjutnya (Bowlby, 1958 dalam Brandon et al., 2009). Dalam hal ini, Bowlby (1988) menjelaskan bahwa 
seorang ibu yang selalu ada dan bersikap responsif terhadap kebutuhan bayinya akan membangun rasa aman dalam diri anak yang akan memengaruhi kepribadian anak tersebut dan berdampak hingga ia dewasa.

Mengamati ikatan yang terjadi antara ibu dan bayi yang baru dilahirkan, serta kesedihan pada ibu yang mengalami keguguran atau pada ibu yang bayinya meninggal ketika baru saja dilahirkan, Bowlby menggagas bahwa keterikatan antara bayi dan ibu dimulai jauh sebelum kelahiran (Brandon et al., 2009). Penelitianpenelitian terbaru turut mendukung hal tersebut di mana penelitian terbaru menunjukkan bahwa kelekatan orang tua khususnya ibu dengan janin dalam kandungan, atau yang disebut Maternal Fetal Attachment (MFA), berpengaruh terhadap optimalisasi perkembangan bayi tersebut setelah dilahirkan (Alhusen, Hayat, \& Gross, 2013).

Kelekatan ibu hamil dan janin tersebut juga memiliki implikasi penting dalam kesehatan ibu dan bayi setelah kelahiran dan memengaruhi hubungan yang dikembangkan ibu dengan anaknya serta kualitas perawatan yang disediakan ibu kepada bayinya (Punamäki, Isosävi, Qouta, Kuittinen, \& Diab, 2017). Penelitian sebelumnya juga membuktikan bahwa jika ikatan ibu dengan anaknya yang belum lahir memiliki kualitas yang baik, hal ini secara positif memengaruhi kemampuan investigasi dan penyelesaian masalah anak, sosialisasi, dan perkembangan prasekolah (Golbasi et al., 2015). Kehadiran MFA memiliki manfaat psikologis untuk membantu wanita dalam beradaptasi dengan kehamilan serta membantu kesiapan untuk menjadi ibu (Golbasi et al., 2015).

Melihat pengaruh kelekatan ibu hamil terhadap janin dalam kandungan yang signifikan terhadap ibu dan bayi, maka kelekatan tersebut merupakan hal yang penting untuk diperhatikan. Untuk dapat meningkatkan kelekatan hubungan antara ibu dan bayi, maka kita perlu mencari tahu faktor apa saja yang dapat memengaruhi kelekatan hubungan antara ibu dan janin dalam kandungan. Sayangnya, belum ada studi literatur yang memeriksa, hal-hal apa saja yang memengaruhi kelekatan hubungan antara ibu dan janin dalam kandungan. Berdasarkan hal tersebut, maka tinjauan literatur ini hendak memeriksa mengenai: "Faktor-faktor apa saja yang memengaruhi kelekatan hubungan antara ibu dan bayi yang berada dalam kandungan (maternal fetal attachment)?"

Tinjauan literatur ini memeriksa artikel-artikel penelitian yang dipublikasikan sejak tahun 2015 hingga 2018. Diharapkan, penelitian studi literatur ini dapat memberikan informasi mengenai hal-hal yang memengaruhi kelekatan ibu dan janin sehingga dapat berguna dalam penelitian selanjutnya sebagai pijakan atas hal-hal yang telah diteliti sebelumnya.

\section{Pembahasan}

Pada tinjauan literatur, data diambil dari penelitian-penelitian sebelumnya yang sesuai dengan topik yang sedang dibahas. Target populasi dalam tinjauan literatur adalah keseluruhan artikel penelitian yang sesuai dengan kriteria pembahasan (Cooper, 2010).

\section{Kriteria Eksklusi dan Inklusi}

Untuk menentukan populasi dalam tinjauan literatur, digunakan kriteria eksklusi dan inklusi. Kriteria inklusi digunakan untuk menentukan artikel penelitian mana saja yang sesuai dengan kriteria yang akan dibahas. Kemudian 
kriteria eksklusi digunakan untuk menentukan artikel penelitian mana saja yang tidak sesuai dengan kriteria topik yang akan dibahas (Cooper, 2010).

Dalam penelitian ini, dipilih artikelartikel dari penelitian sebelumnya yang meneliti tentang faktor-faktor yang memengaruhi kelekatan hubungan ibu dan bayi dalam kandungan atau maternal fetal attachment. Rentang waktu artikel yang dimasukkan adalah artikel penelitian yang dipublikasikan dari tahun 2015 hingga 2018. Hal ini karena artikel-artikel penelitian mengenai maternal fetal attachment yang sudah lama bisa jadi telah terpatahkan atau terdukung oleh artikelartikel penelitian terbaru. Oleh karena itu tinjauan literatur ini mengambil artikel penelitian tiga tahun terakhir.

Ustunsoz, Guvenc, Akyuz, \& Oflaz (2010) menjelaskan definisi fetus attachment secara teoretis sebagai sejauh mana wanita terlibat dalam perilaku yang mewakili afiliasi dan interaksi dengan anak yang belum lahir atau masih berada dalam kandungan. Oleh karena itu tinjauan literatur ini hendak melihat dari tinjauan literatur, hal-hal apa saja yang dapat memengaruhi kelekatan ibu hamil dengan janin dalam kandungan. Artikel penelitian yang diambil mencakup partisipan dari berbagai usia serta mencakup kehamilan pertama (primipara), atau kehamilan kedua dan seterusnya (multipara).

Artikel penelitian yang tidak membahas mengenai faktor-faktor yang memengaruhi kelekatan ibu hamil dengan bayi dalam kandungan, tidak dimasukkan ke dalam tinjauan literatur ini. Sebagai contoh, artikel yang hanya membahas mengenai alat ukur maternal fetal attachment, atau yang membahas kelekatan ibu hamil terhadap bayi dalam kandungan sebagai variabel bebas, tidak disertakan.
Artikel yang merupakan duplikasi atau artikel yang sama yang didapatkan dari mesin pencari yang berbeda juga tidak disertakan.

\section{Prosedur Pencarian}

Pencarian sistematis dilakukan dalam Bahasa Indonesia dan Bahasa Inggris. Pencarian berbahasa Inggris dilakukan untuk mendapatkan artikel jurnal internasional, sedangkan pencarian berbahasa Indonesia dilakukan untuk mendapatkan gambaran penelitian mengenai maternal fetal attachment khusus di Indonesia sehingga kita dapat mengetahui sejauh mana penelitian di Indonesia mengenai topik tersebut.

Pencarian berbahasa Inggris dilakukan pada mesin pencari elektronik EBSCOhost, Taylor \& Francis Online, dan ProQuest. Pencarian dalam bahasa Indonesia dilakukan pada mesin pencari Google Scholar. Penulis melakukan pencarian untuk artikel yang terbit antara bulan Januari 2015 hingga November 2018. Persyaratan seleksi artikel yaitu hanya mengambil artikel yang memiliki teks lengkap yang ditinjau ulang secara akademik (scholarly peer reviewed) serta menyediakan referensi (references available).

Pencarian dalam bahasa inggris dilakukan dengan menggunakan kata-kata kunci berikut: 'Fetus Attachment' AND 'Maternal Fetal Attachment'. Pada mesin pencari Taylor \& Francis Online, hanya dimasukkan hasil yang termasuk subjek "behavioral science", sebab subjek lain seperti "health" akan mengacaukan hasil pencarian yang diharapkan berhubungan dengan variabel psikologi. Pencarian berbahasa Indonesia dilakukan dengan menggunakan kombinasi kata kunci "faktor yang mempengaruhi" dan "maternal fetal attachment". 


\section{Ekstraksi Data}

Berdasarkan prosedur penelusuran yang telah dijelaskan sebelumnya, terdapat 349 artikel yang masuk dalam kategori inklusi untuk dianalisis dalam penelitian tinjauan literatur ini. Setelah melakukan screening artikel berdasarkan pada kriteria eksklusi, maka hanya tersisa 9 artikel penelitian yang akan dikaji.

Dari hasil pencarian dari 4 mesin pencari, didapatkan 349 artikel penelitian. Setelah dicek, kemudian 2 artikel dikeluarkan karena merupakan duplikasi. Dari 347 artikel yang tersisa, kemudian 323 artikel dikeluarkan karena tidak membahas MFA secara langsung. Selanjutnya dari 24 artikel yang tersisa kemudian 4 artikel dikeluarkan karena membahas alat ukur MFA, kemudian 10 artikel dikeluarkan karena membahas MFA sebagai variabel bebas, dan 1 artikel dikeluarkan karena merupakan tinjauan literatur. Kemudian didapatkan 9 artikel yang meneliti tentang MFA sebagai variabel terikat yang akan dianalisis dalam tinjauan literatur ini. 9 Artikel tersebut terdiri atas 7 artikel berbahasa Inggris dan 2 artikel berbahasa Indonesia.

\section{Tahun dan Lokasi Penelitian}

Artikel penelitian yang dimasukkan dalam tinjauan literatur ini adalah dari sejak tahun 2015 hingga tahun 2018. Terdapat 2 artikel penelitian yang diterbitkan pada tahun 2015, 2 artikel penelitian yang terbit tahun 2016, 2 artikel yang terbit tahun 2017, serta 3 artikel yang terbit pada 2018. Selanjutnya, penelitian dalam bahasa Inggris memasukkan beberapa negara yang menjadi lokasi penelitian dalam artikel-artikel yang termasuk tinjauan literatur ini. Beberapa negara tersebut yaitu Swedia terdiri atas 1 artikel penelitian, Iran terdiri dari 2 artikel penelitian, 1 artikel penelitian dari Taiwan, Amerika
Serikat sebanyak 1 artikel penelitian, Portugal sebanyak 1 artikel penelitian, dan Finlandia sebanyak 1 artikel penelitian. Kemudian untuk penelitian berbahasa Indonesia, lokasi penelitian dilakukan di Indonesia sebanyak 2 artikel penelitian, yang dilakukan di Kota Palangka Raya dan Yogyakarta.

\section{Karakteristik Partisipan}

Dari seluruh hasil pencarian, terdapat 9 artikel penelitian yang meneliti tentang maternal fetal attachment sebagai variabel terikat (dependent variable). Partisipan yang menjadi objek dalam penelitian pada artikel-artikel yang dianalisis mencakup usia 18 hingga 40 tahun (Rubertsson, Pallant, Sydsjö, Haines, \& Hildingsson, 2015; Abazari, Pouraboli, Tavakoli, Aflatoonian, \& Kohan, 2017; Hopkins, Miller, Butler, Gibson, Hedrick, \& Boyle, 2018), ibu rumah tangga dan ibu bekerja (Abazari, et al., 2017) dengan jenjang pendidikan ibu lulusan SD hingga lulusan perguruan tinggi (Rubertsson et al, 2015; Abazari et al., 2017). Jenis kehamilan partisipan pada 7 artikel penelitian ini adalah kehamilan pertama (primiparous/ nulliparous) (Rubertsson et al., 2015; Mohamadirizi \& Kordi, 2016; Abazari, et al., 2017) dan kehamilan kedua dan seterusnya (multiparous) (Rubertsson et al., 2015; Abazari et al., 2017), usia kehamilan trimester kedua (Camarneiro \& Justo, 2017; Hopkins et al., 2018; Chang, Yu, Chen, \& Chen, 2015) dan trimester kehamilan ketiga (Mohamadirizi \& Kordi, 2016; Rusanen, Lahikainen, Pölkki, Saarenpää-Heikkilä, \& Paavonen, 2018; Alfianty \& Suryaningsih, 2016), partisipan yang memiliki riwayat keguguran dan juga yang tidak memiliki riwayat keguguran dan/atau aborsi (Abazari, et al., 2017; Rubertsson, et.al., 2015), kehamilan dengan risiko rendah (Camarneiro \& 
Justo, 2017) dan kehamilan dengan risiko tinggi (Hopkins et al., 2018), serta kehamilan yang direncanakan dan tidak direncanakan (Abazari et al., 2017). Berdasarkan kewarganegaraan partisipan, terdapat kewarganegaraan Iran (Mohamadirizi \& Kordi, 2016; Abazari et al., 2017), Swedia (Rubertsson et al., 2015),
Portugal (Camarneiro \& Justo, 2017), Finland (Rusanen et al., 2018), USA (Hopkins et al., 2018), dan Taiwan (Chang et al., 2015).

Beberapa penelitian juga mengukur pengaruh variabel demografis terhadap maternal fetal attachment (MFA) yang hasilnya dapat pada Tabel 1.

Tabel 1.

Daftar Variabel Demografis yang Memengaruhi Maternal Fetal Attachment

\begin{tabular}{|c|c|c|c|}
\hline No & Variabel Demografis & Pengaruh Terhadap MFA & Artikel \\
\hline \multirow[t]{5}{*}{1} & Usia partisipan & $\begin{array}{l}\text { Berpengaruh terhadap MFA, yaitu ibu } \\
\text { dengan usia kurang dari } 25 \text { tahun } \\
\text { mendapatkan skor MFA lebih tinggi } \\
\text { dibandingkan dengan ibu di atas usia } 25 \\
\text { tahun }\end{array}$ & (Rubertsson et al., 2015) \\
\hline & & Tidak berpengaruh terhadap MFA & (Abazari et al., 2017) \\
\hline & & $\begin{array}{l}\text { Berpengaruh terhadap MFA, yaitu usia } \\
\text { yang lebih tua dihubungkan dengan skor } \\
\text { MFA yang lebih rendah }\end{array}$ & (Hopkins et al., 2018) \\
\hline & & $\begin{array}{l}\text { Berpengaruh terhadap MFA, yaitu usia } \\
\text { yang lebih muda dikaitkan dengan skor } \\
\text { MFA yang lebih tinggi }\end{array}$ & $\begin{array}{l}\text { (Camarneiro \& Justo, } \\
\text { 2017) }\end{array}$ \\
\hline & & $\begin{array}{l}\text { Berpengaruh terhadap MFA, yaitu usia } \\
\text { perempuan yang lebih muda dikaitkan } \\
\text { dengan harapan yang lebih positif atas } \\
\text { hubungannya dengan bayi }\end{array}$ & (Rusanen et al., 2018) \\
\hline \multirow[t]{5}{*}{2} & Jenjang pendidikan & $\begin{array}{l}\text { Berpengaruh terhadap MFA, yaitu } \\
\text { perempuan dengan pendidikan sekolah } \\
\text { dasar atau menengah mendapat skor MFA } \\
\text { lebih tinggi dibandingkan dengan wanita } \\
\text { dengan pendidikan perguruan tinggi atau } \\
\text { universitas }\end{array}$ & (Rubertsson et al., 2015) \\
\hline & & $\begin{array}{l}\text { Berpengaruh terhadap MFA, yaitu Tingkat } \\
\text { kelekatan ibu-janin dengan pendidikan } \\
\text { universitas lebih tinggi daripada kelompok } \\
\text { jenjang pendidikan yang lebih rendah }\end{array}$ & (Abazari et al., 2017) \\
\hline & & Tidak berpengaruh terhadap MFA & (Hopkins et al., 2018) \\
\hline & & $\begin{array}{l}\text { Berpengaruh terhadap MFA, yaitu MFA } \\
\text { ditemukan lebih tinggi pada perempuan } \\
\text { dengan pendidikan yang lebih rendah }\end{array}$ & $\begin{array}{l}\text { (Camarneiro \& Justo, } \\
\text { 2017) }\end{array}$ \\
\hline & & $\begin{array}{l}\text { Berpengaruh terhadap MFA, yaitu } \\
\text { pendidikan ibu yang lebih tinggi } \\
\text { dihubungkan dengan skor MFA yang lebih } \\
\text { rendah }\end{array}$ & (Rusanen et al., 2018) \\
\hline
\end{tabular}




\begin{tabular}{|c|c|c|c|}
\hline No & Variabel Demografis & Pengaruh Terhadap MFA & Artikel \\
\hline 3 & $\begin{array}{l}\text { Parity (jenis } \\
\text { kehamilan) }\end{array}$ & $\begin{array}{l}\text { Berpengaruh terhadap MFA, yaitu } \\
\text { perempuan dengan kehamilan multiparous } \\
\text { mencatat skor yang lebih rendah } \\
\text { dibandingkan dengan primiparous }\end{array}$ & (Rubertsson et al., 2015) \\
\hline 4 & Riwayat aborsi & Tidak berpengaruh terhadap MFA & (Abazari et al., 2017) \\
\hline 5 & $\begin{array}{l}\text { Perencanaan } \\
\text { kehamilan (kehamilan } \\
\text { yang diinginkan/ } \\
\text { tidak) }\end{array}$ & $\begin{array}{l}\text { Tidak berpengaruh terhadap MFA } \\
\text { Berpengaruh terhadap MFA, yaitu } \\
\text { kehamilan yang terencana dihubungkan } \\
\text { dengan skor MFA yang lebih tinggi } \\
\text { dibandingkan dengan kehamilan yang } \\
\text { tidak terencana }\end{array}$ & $\begin{array}{l}\text { (Abazari et al., 2017) } \\
\text { (Camarneiro \& Justo, } \\
\text { 2017) }\end{array}$ \\
\hline 6 & Pekerjaan ibu & $\begin{array}{l}\text { Tidak berpengaruh terhadap MFA } \\
\text { Tidak berpengaruh terhadap MFA }\end{array}$ & $\begin{array}{l}\text { (Abazari et al., 2017) } \\
\text { (Camarneiro \& Justo, } \\
\text { 2017) }\end{array}$ \\
\hline 7 & Riwayat infertilitas & Tidak berpengaruh terhadap MFA & (Abazari et al., 2017) \\
\hline 8 & Kelainan janin & Tidak berpengaruh terhadap MFA & (Abazari et al., 2017) \\
\hline 9 & $\begin{array}{l}\text { Jumlah anak } \\
\text { sebelumnya }\end{array}$ & $\begin{array}{l}\text { Berpengaruh terhadap MFA, yaitu } \\
\text { perempuan yang tidak memiliki anak } \\
\text { sebelumnya dikaitkan dengan skor MFA } \\
\text { yang lebih tinggi jika dibandingkan dengan } \\
\text { yang telah memiliki anak sebelumnya }\end{array}$ & (Abazari et al., 2017) \\
\hline 10 & Usia kehamilan & $\begin{array}{l}\text { Tidak berpengaruh terhadap MFA } \\
\text { Berpengaruh terhadap MFA } \\
\text { Berpengaruh terhadap MFA }\end{array}$ & $\begin{array}{l}\text { (Hopkins et al., 2018) } \\
\text { (Camarneiro \& Justo, } \\
\text { 2017) } \\
\text { (Sukriani \& } \\
\text { Suryaningsih, 2018) }\end{array}$ \\
\hline 11 & $\begin{array}{l}\text { Jumlah kehamilan } \\
\text { sebelumnya }\end{array}$ & Tidak berpengaruh terhadap MFA & (Hopkins et al., 2018) \\
\hline 12 & $\begin{array}{l}\text { Kondisi kehamilan } \\
\text { sebelumnya }\end{array}$ & Berpengaruh terhadap MFA & $\begin{array}{l}\text { (Camarneiro \& Justo, } \\
\text { 2017) }\end{array}$ \\
\hline 13 & $\begin{array}{l}\text { Risiko/ gangguan } \\
\text { kehamilan }\end{array}$ & $\begin{array}{l}\text { Tidak berpengaruh terhadap MFA } \\
\text { Berpengaruh terhadap MFA }\end{array}$ & $\begin{array}{l}\text { (Hopkins et al., 2018) } \\
\text { (Camarneiro \& Justo, } \\
\text { 2017) }\end{array}$ \\
\hline 14 & $\begin{array}{l}\text { Jumlah kelahiran } \\
\text { hidup }\end{array}$ & Tidak berpengaruh terhadap MFA & (Hopkins et al., 2018) \\
\hline 15 & Status sosial ekonomi & $\begin{array}{l}\text { Berpengaruh terhadap MFA, yaitu MFA } \\
\text { ditemukan lebih tinggi pada perempuan } \\
\text { dengan status sosial ekonomi yang lebih } \\
\text { tinggi }\end{array}$ & $\begin{array}{l}\text { (Camarneiro \& Justo, } \\
\text { 2017) }\end{array}$ \\
\hline
\end{tabular}

\section{Temuan Utama}

Dari 9 studi yang diteliti dalam penelitian tinjauan literatur ini, terdapat beberapa variabel yang diteliti hubungannya terhadap kelekatan ibu dan janin. Variabel yang diteliti tersebut terdiri atas variabel demografis dan faktor klinis, variabel psikologis, dan variabel intervensi. 
Pada variabel demografis dan faktor klinis kehamilan, sebagaimana telah dijabarkan dalam poin karakteristik partisipan, terdapat beberapa variabel demografis yang berpengaruh terhadap kelekatan hubungan antara ibu dan janin, yaitu variabel usia, pendidikan ibu, status sosial ekonomi, jumlah anak sebelumnya, jenis kehamilan (parity), perencanaan kehamilan, kehamilan sebelumnya, gangguan kehamilan dan usia kehamilan (Abazari, et al., 2017; Camarneiro \& Justo, 2017; Hopkins, et al., 2018; Rubertsson, et al., 2015; Rusanen, et al., 2018).

Untuk variabel psikologis yang diteliti dari studi literatur, yaitu terdapat variabel depresi, dukungan sosial, kecemasan, selfcompassion, suasana keluarga, serta kemampuan ibu untuk dekat dan percaya terhadap orang dewasa lain. Variabelvariabel tersebut berpengaruh secara signifikan terhadap tingkat kelekatan hubungan antara ibu hamil dengan janin dalam kandungan.

Perempuan yang paling berisiko memiliki tingkat kelekatan yang rendah adalah mereka yang depresi, memiliki lebih banyak perasaan negatif mengenai kelahiran yang semakin dekat dan perasaan negatif mengenai orang tua, dan mereka yang menganggap diri mereka kurang mendapat dukungan dari pasangan dan keluarga. Depresi ibu sebelum melahirkan memiliki efek negatif pada kelekatan antara ibu dan bayi. Gejala depresi ibu sebelum melahirkan juga memiliki dampak yang lebih kuat pada kurang responsifnya ibu terhadap bayinya dibandingkan dengan gejala depresi setelah melahirkan (Rubertsson, et al., 2015). Kemudian hasil penelitian Abazari, et al. (2017) di Iran, menunjukkan adanya hubungan langsung antara kecemasan dan kelekatan hubungan antara ibu dan janin. Penelitian ini juga menunjukkan bahwa kekhawatiran ibu atas kelainan janin dan aborsi diikuti oleh peningkatan kelekatan hubungan ibu-janin di samping peningkatan jumlah kecemasan. Dalam hal ini Abazari, et al., (2017) menuliskan bahwa secara psikologis diperlukan adanya keseimbangan antara kecemasan dan kelekatan terutama dalam kehamilan.

Kemudian hasil penelitian Mohamadirizi \& Kordi (2016) di Iran menunjukkan adanya hubungan positif antara kelekatan ibu dengan janin dalam kandungan dengan self-compassion. Selfcompassion merupakan gabungan dari kebaikan diri, penilaian diri, kehadiran pikiran, simpati ekstrem, kesamaan pada manusia, dan isolasi.

Variabel psikologis lainnya ditemukan dalam studi yang dilakukan Hopkins, et al. (2018) menunjukkan bahwa kelekatan hubungan antara ibu dan janin berkaitan dengan kecemasan dan dukungan sosial. Temuan ini menunjukkan bahwa intervensi untuk mengurangi kecemasan dan meningkatkan dukungan sosial dapat meningkatkan kelekatan hubungan antara ibu dan janin. Secara khusus, hubungan antara kecemasan dan kelekatan ibu-janin dilemahkan ketika dukungan sosial tinggi. Dengan demikian, temuan ini menunjukkan bahwa dukungan sosial memiliki baik efek langsung pada hubungan yang berkembang antara wanita hamil dan anaknya yang belum lahir dan, juga, berfungsi untuk melemahkan efek dari variabel risiko lainnya, seperti kecemasan (Alfianty \& Suryaningsih, 2016).

Kemudian Rusanen, et al. (2018) juga menemukan bahwa prediktor yang paling kuat dari harapan pralahir ibu terhadap janin dalam kandungan adalah kedekatan ibu dalam hubungan orang dewasa, tingkat gejala depresi, dan suasana keluarga. Rusanen, et al. (2018) menjelaskan bahwa depresi terkait dengan harapan ibu yang 
lebih negatif pada kelekatan ibu-janin serta harapan yang negatif atas regulasi dalam pola tidur dan makan bayi. Suasana keluarga yang positif dan kemampuan ibu untuk dekat dan percaya terhadap orang dewasa lain terkait dengan harapan yang lebih positif atas kelekatan ibu-janin.

Untuk variabel intervensi, terdapat satu studi yang dilakukan oleh Chang et al. (2015) di Taiwan yang menjelaskan tentang hubungan terapi musik terhadap kelekatan hubungan antara ibu dan janin. Penelitian ini mendukung efek positif mendengarkan jenis musik tertentu pada pendidikan pralahir ibu dan relaksasi diri ibu. Namun penelitian ini menunjukkan bahwa mendengarkan musik tidak memengaruhi kelekatan hubungan antara ibu dan janin.

\section{Penutup}

Dari hasil tinjauan literatur ini, seluruh faktor yang berkontribusi terhadap kelekatan ibu hamil dan janin dapat dikategorikan ke dalam beberapa jenis variabel besar, yaitu variabel demografis, variabel psikologis, dan variabel intervensi. Beberapa variabel demografis dan variabel psikologi, secara signifikan memengaruhi kelekatan hubungan antara ibu hamil dengan janin dalam kandungan. Variabel psikologis yang secara positif memengaruhi kelakatan ibu dan janin yaitu dukungan sosial (Alfianty \& Suryaningsih, 2016), self-compassion (Mohamadirizi \& Kordi, 2016), suasana keluarga yang positif, serta kemampuan ibu untuk dekat dan percaya terhadap orang dewasa lain (Rusanen et al., 2018).

Di lain pihak, variabel psikologis yang signifikan memengaruhi kelekatan ibu dan janin secara negatif yaitu depresi dan kecemasan (Rusanen, et al., 2018; Hopkins, et al., 2018). Meski demikian, hubungan antara variabel kecemasan dengan tingkat kelekatan antara ibu hamil dan janin masih belum konsisten. Penelitian sebelumnya yang telah dilakukan Hopkins et al. (2018) menjelaskan bahwa kecemasan dapat melemahkan tingkat kelekatan antara ibu hamil dan janin. Di lain pihak, penelitian yang pernah dilakukan Abazari et al., (2017) menunjukkan sebaliknya, yaitu bahwa tingginya kecemasan dapat meningkatkan kelekatan hubungan antara ibu hamil dan janin. Belum terdapat penelitian yang menjelaskan mengenai inkonsistensi tersebut.

Perempuan yang paling berisiko memiliki tingkat kelekatan yang rendah adalah mereka yang depresi (Hopkins et al., 2018), kurang mendapatkan dukungan dari pasangan dan keluarga, memiliki suasana keluarga yang negatif, serta ketidakmampuan ibu untuk dekat dan percaya kepada orang dewasa lain (Rusanen, et al., 2018).

Berdasarkan temuan ini, kita dapat melihat berbagai faktor psikologis yang memengaruhi kelekatan ibu terhadap janin dalam kandungan. Di antara faktor psikologis yang berpengaruh positif terhadap tingkat kelekatan ibu hamil dan janin, yaitu dukungan sosial khususnya dari keluarga dan pasangan. Kemudian, variabel yang berpengaruh negatif terhadap tingkat kelekatan antara ibu hamil dan janin yaitu gejala depresi dan kecemasan yang pada akhirnya akan berpengaruh negatif terhadap kesehatan ibu dan perkembangan bayi pasca kelahiran.

Di Indonesia sendiri, penelitian mengenai variabel psikologis terhadap kelekatan ibu dan janin belum banyak diteliti. Penelitian yang telah ada dan dilakukan terkait dengan tingkat kelekatan ibu hamil dan janin, yaitu mengenai hubungan dukungan keluarga (Alfianty \& 
Suryaningsih, 2016), serta usia kehamilan (Sukriani \& Suryaningsih, 2018).

Di lain pihak, berdasarkan temuan hubungan antara variabel demografis dan kelekatan ibu dan janin, terdapat hubungan yang menarik antara variabel pendidikan ibu dengan tingkat kelekatan hubungan antara ibu dan bayi, yaitu semakin tinggi tingkat pendidikan ibu, maka tingkat kelekatan hubungan antara ibu dan janin akan semakin berkurang (Rubertsson, et al., 2015; Camarneiro \& Justo, 2017; Rusanen, et al., 2018). Hal ini dapat menjadi saran untuk penelitian berikutnya untuk dapat menjelaskan apa yang menjadi penyebab hubungan negatif dari tingkat pendidikan ibu hamil dengan tingkat kelekatan hubungan antara ibu dan janin.

\section{Daftar Pustaka}

Abazari, F., Pouraboli, B., Tavakoli, P., Aflatoonian, M., \& Kohan, M. (2017). Anxiety and its relationship with maternal fetal attachment in pregnant women in southeast of iran. IManager's Journal on Nursing, 7(3), 1627. Diunduh dari http://remotelib.ui.ac.id:2090/10.26634/jnur.7.3.13788

Alhusen, J. L., Hayat, M. J., \& Gross, D. (2013). A longitudinal study of maternal attachment and infant developmental outcomes. Arch Womens Ment Health, 16, 521-529. doi: 10.1007/s00737-013-0357-8

Alfianty, F. N., \& Suryaningsih, E. K. (2016). Naskah publikasi: Hubungan dukungan keluarga dengan maternalfetal attachment pada ibu hamil trimester III di puskesmas Jetis kota Yogyakarta [pdf file]. Diunduh dari http://digilib.unisayogya.ac.id/1992/1/F ENNY\%20NUR\%20ALVIANTY_20151 0104385_NASKAH\%20PUBLIKASI.pdf
Bowlby, J. (1988). A secure base: Clinical applications of attachment theory. London: Routledge.

Brandon, A. R., Pitts, S., Denton, W. H., Stringer, C. A., \& Evans, H. M. (2009). A history of the theory of prenatal attachment. J Prenat Perinat Psychol Health, 23(4), 201-222.

Camarneiro, A. P. F., \& Justo, J. M. R. M. (2017). Prenatal attachment and sociodemographic and clinical factors in Portuguese couples. Journal of Reproductive and Infant Psychology, 35(3), 212-222. doi: 10.1080/ 02646838.2017.1297889

Chang, H., Yu, C., Chen, S., \& Chen, C. (2015). The effects of music listening on psychosocial stress and maternal-fetal attachment during pregnancy. Complementary Therapies in Medicine, 23(4), 509-515. doi: $\underline{10.1016 /}$ j.ctim.2015.05.002

Condon, J. T. (1993). The assessment of antenatal emotional attachment: Development of a questionnaire instrument. British Journal of Medical Psychology, 66, 167-183. doi: 10.1111/j.2044- 8341.1993.tb01739.x

Cooper, H. (2010). Research synthesis and meta-analysis: A step by step approach. Los Angeles: SAGE Publication.

Cunningham, F. D. (2008). Maternal/fetal attachment: Associations among family relationships, maternal health practices, and antenatal attachment (Order No. 3326894). Available from Health \& Medical Collection; Nursing \& Allied Health Database; ProQuest Dissertations \& Theses Global. (304448204). Diunduh dari https://remote-lib.ui.ac.id:2155/ docview/304448204? accountid $=17242$

Erviana, E. (2014, December 5). Angka kematian ibu tertinggi ada di Jawa 
Barat. Kompas.com. Retrieved December 2, 2018 from https://www.academia.edu/19442291/P anduan_SDGs_Sustainable_Developm ent_Goals_untuk_Pemerintah_Daerah

Golbasi, Z., Ucar, T., \& Tugut, N. (2015). Validity and reliability of the Turkish version of the Maternal Antenatal Attachment Scale. Japan Journal of Nursing Science, 12(2015), 154-161. doi: 10.1111/jins.12052

Hopkins, J., Miller, J. L., Butler, K., Gibson, L., Hedrick, L., \& Boyle, D. A. (2018). The relation between social support, anxiety and distress symptoms and maternal fetal attachment. Journal of Reproductive and Infant Psychology, 36(4), 381-392. doi: 10.1080/02646838. $\underline{2018.1466385}$

Kementerian Kesehatan RI. (2014). Infodatin mother's day: Situasi kesehatan ibu. Jakarta Selatan: Pusat Data dan Informasi Kementrian Kesehatan RI. Retrieved from: http://www.depkes.go.id/resources/do wnload/pusdatin/infodatin/infodatinibu.pdf

Mgawadere, F., Kana, T., \& van den Broek, N. (2017). Measuring maternal mortality: A systematic review of methods used to obtain estimates of the maternal mortality ratio (MMR) in low- and middle-income countries. British Medical Bulletin, 121(1), 121-134. doi: $10.1093 / \mathrm{bmb} / \mathrm{ldw} 056$

Mohamadirizi, S., \& Kordi, M. (2016). The relationship between multi-dimensional self-compassion and fetalmaternal attachment in prenatal period in referred women to mashhad health center. Journal of Education and Health Promotion, 5. doi: 10.4103/2277$\underline{9531.184550}$
Punamäki, R.-L., Isosävi, S., Qouta, S. R., Kuittinen, S., \& Diab, S. Y. (2017). War trauma and maternal-fetal attachment predicting maternal mental health, infant development, and dyadic interaction in Palestinian families. Attachment \& Human Development, 19(5), 463-486. doi: 10.1080/ $\underline{14616734.2017 .1330833}$

Retnowati, S. (2011). Pengaruh pelatihan relaksasi dengan dzikir untuk mengatasi kecemasan ibu hamil pertama. Psikoislamika, 8(1), 1-22. Retrieved from: http://ejournal.uinmalang.ac.id/index.php/psiko/article/vi ew/1543/2717

Rubertsson, C., Pallant, J. F., Sydsjö, G., Haines, H. M., \& Hildingsson, I. (2015). Maternal depressive symptoms have a negative impact on prenatal attachment - findings from a Swedish community sample. Journal of Reproductive \& Infant Psychology, 33(2), 153-164. doi: 10.1080/02646838.2014. $\underline{992009}$

Rusanen, E., Lahikainen, A. R., Pölkki, P., Saarenpää-Heikkilä, O. \& Paavonen, E. J. (2018). The significance of supportive and undermining elements in the maternal representations of an unborn baby. Journal of Reproductive and Infant Psychology, 36(3), 261-275. doi: $\underline{10.1080 / 02646838.2018 .1462476}$

Sukriani, W., \& Suryaningsih, E. K. (2018). Faktor yang berhubungan dengan skor MFA pada ibu hamil. Jurnal Kesehatan, 9(2), 185-191. Retrieved from: http://ejurnal.poltekkes-tjk.ac.id/ index.php//K

Ustunsoz, A., Guvenc, G., Akyuz, A., Oflaz, F. (2010). Comparison of maternal-and paternal-fetal attachment in Turkish couples. Midwifery, 26, e1-e9. doi: 10.1016/j.midw.2009.12.006 